\title{
製造作業における「指差呼称」法と疲労度の関連 一医薬品製造工場にて一
}

Correlation between "Pointing and Calling" method in manufacturing and degree of fatigue at a pharmaceutical manufacturing plant

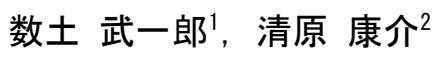

1同仁医薬化工株式会社統括部，2大妻女子大学家政学部食物学科公衆衛生学研究室

Takeichiro Sudo $^{1}$, Kosuke Kiyohara ${ }^{2}$

${ }^{1}$ General Affairs Division, Dojin Iyaku-Kako Co., Ltd.

5-2-2, Yayoi-cho, Nakano-ku, Tokyo, 164-0013 Japan

${ }^{2}$ Department of Food Science, Faculty of Home Economics, Otsuma Women's University

12 Sanban-cho, Chiyoda-ku, Tokyo, 102-8357 Japan

キーワード：指差呼称，安全，ヒューマンエラー，医薬品製造

Key words : Pointing and Calling, Safety, Human error, Pharmaceutical manufacturing

\begin{abstract}
抄録
指差呼称は安全確認やヒューマンエラー防止を目的として，指差しを行い，その名称や状態を声 に出して確認することである。我が国では，指差呼称は有効な安全対策として各業界で推奨され， 医療現場や製造業等で幅広く実施されている，本研究では，医薬品製造の実生産ラインにおいて， 指差呼称の実施回数を増やした際の作業員の肉体的・精神的疲労度およびヒューマンエラーの発生 回数の変化について検討した. D製薬会社福島工場の製造作業員 30 名を対象に, 1 日の作業終了後に 腕, 口, 目, 足, 精神の疲労度をVisual Analog Scaleにより10日間測定した. その後, 作業中の指差 呼称実施回数を通常の3倍として10日間勤務してもらい, 同様に疲労度を測定して従前と比較した.

その結果, 指差呼称実施回数を3倍とした期間は，通常回数の期間と比較して，腕，目，精神の 疲労度が有意に上昇した $(\mathrm{p}<0.05)$ ．口と足の疲労度には有意な変化は見られなかった。一方，ヒュ ーマンエラーは全研究期間をとおして一度も発生しなかった。

以上の結果より，指差呼称実施回数を増やすことは作業員の疲労度を増大させる一方で，短期的 にはヒューマンエラーの発生回数に影響しない可能性が示唆された. ただし，本研究の調查期間は 計20日間と短く, ヒューマンエラー発生回数の差を把握するには十分な観察期間ではなかった可能 性がある.今後はより長期的なモニタリングを行い, 指差呼称の実施回数とヒューマンエラーの発 生との関係を評価していく必要がある.
\end{abstract}

\section{1. 背景}

作業現場におけるヒューマンエラー防止策とし ては，エラーマネジメントとしてのヒヤリハット 活動や危険予知活動, エラーコントロールとして のストップ・ルックや指差呼称等が推奨されてお り, 中央労働災害防止協会より具体的な実施方法 が指南されている ${ }^{[1-3]}$. 指差呼称とは, 作業者が注 意すべき対象を指で差し確認すべき状態を声に出 すものである．指差呼称を実施することによるヒ
ユーマンエラー防止効果については多くの先行研 究がなされ, 効果が実証されている ${ }^{[4-8]}$. そのため, 我が国では様々な作業現場でエラーを防止する方 法として導入され，安全及び品質向上に寄与して いる.

指差呼称がエラー防止に寄与する理由としては, 先行研究から下記 5 点が指摘されている.

（1）指差による視線停留効果 …刺激を正確かつ鮮明に網膜に伝える ${ }^{[8]}$. 
（2）指差しによる反応遅延の焦燥抑制効果

…知覚と反応間のタイムラグにより焦燥反 応を抑制する ${ }^{[6]}$.

（3）呼称による記憶強化効果

…呼称は名称を思い出して言うので意識を

対象に集中させ記憶形成を助ける ${ }^{[8]}$.

（4）指差・呼称併用によるエラーの気づき

…指差呼称は, 視覚・聴覚等の動員により

認知の精度を高める ${ }^{[8]}$.

（5）指差呼称による覚醒効果

…顎・手・腕の筋肉運動が刺激となって大

脳活動レベルがあがる ${ }^{[8]}$.

この様に指差呼称の効果は体の動き（運動）に よってその効果をもたらしている，そのため，指 差呼称の回数を増やせばよりエラーを減らすこと ができると考えられる。しかし, 最も適切な指差 呼称の実施回数に関する知見は不足しているのが 現状である．指差呼称を実施したほうが実施しな い場合よりも自覚的疲労感が小さくなるとの報告 もあるが ${ }^{[9]}$, 過剩な指差呼称の実施は運動量の増 加により疲労度が増大寸る可能性も考えられる。 疲労度が上がるとヒューマンエラーの発生確率が 増大寸る事も指摘されている ${ }^{[10,11]}$. そのため, 指 差呼称の実施回数と疲労度やヒューマンエラーの 発生との関連について明らかにし, 最も適切な指 差呼称の実施回数を検討する必要がある.

\section{2. 目的}

本研究では，D 製薬会社福島工場の製造作業員 を対象とした介入研究を実施し，製造ラインにお ける指差呼称実施回数の増加が主観的疲労度およ びヒューマンエラーの発生回数に影響を与えるか どうかを明らかにすることを目的とした。

\section{3. 方法}

\section{1. 対象者}

本研究の対象者は, D 製薬会社福島工場に常勤 職員として勤務する薬品製造作業員とした. 本研 究は実製造ラインにおける介入研究であることか ら，研究期間中の作業内容の同一性等を担保でき る最大人数として，対象者を 30 名と設定した.

3.2. 指差呼称の実施方法

$\mathrm{D}$ 社福島工場では作業員に品質・安全に関する 下記の場面で指差呼称を行うよう指導している. 品質に関連する指差呼称は, 個々の医薬品の医薬
品製造販売承認書内の製造工程管理部分において 定める確認対象で実施する ${ }^{[12] 。}$ 具体的な実施例と して，作業員は薬を配合するタンクに決められた 手順で原料を投入する際に, 原料の種類と数量 (重 さ）を間違えないように指差呼称を行っている. また，同タンク内を攪拌する際の回転数や温度と いった監視（メーターの数值読取）の際も同様に 実施している。安全に関する指差呼称は, 安全衛 生法に定める注意個所の他, 安全リスクアセスメ ントによって導き出された注意箇所や行為を対象 として実施する ${ }^{[13]}$. 具体的な実施例として，作業 員は薬を配合する大型タンクの蓋を油圧で開閉す る際，他の作業員が挟まれる位置にいないかどう か，周辺状況を指差呼称により確認している.

\section{3. 研究デザイン}

前後比較介入デザインにより，指差呼称の実施 回数を増やしたことによる主観的疲労度およびヒ ューマンエラーの発生数の変化を評価した(図 1). 本研究は実際の医薬品製造の生産ラインにおいて 行った。まず，2019年 10 月〜11月の対象者の勤 務日に 10 日間連続して通常どおりの指差呼称を 実施してもらい, 勤務終了後に肉体的・精神的疲 労度を測定した (介入前期)。続いて，5 日間のイ ンターバル期間を設けた後, 指差呼称の実施回数 を従前の 3 倍量として 10 日間連続で作業を行って もらい，同様に勤務終了後に肉体的・精神的疲労 度を測定した (介入後期). 指差呼称の実施回数を 3 倍量としたのは, 実生産ラインにおける作業効 率への影響を検討した結果，現実的に実施できる 最大回数は 3 倍が限度であると見積もったためで ある. なお，全ての対象者の作業内容は介入前期・ 後期をとおしてほぼ一定である.

\section{4. 測定項目}

各日の勤務時間終了後に, 腕, 口, 目, 足, 精 神の 5 項目の疲労度について, Visual Analog Scale

（VAS）を用いて測定した。 日本疲労学会の抗疲 労臨床評価ガイドライン ${ }^{[14]}$ に基づき, $100 \mathrm{~mm} の$

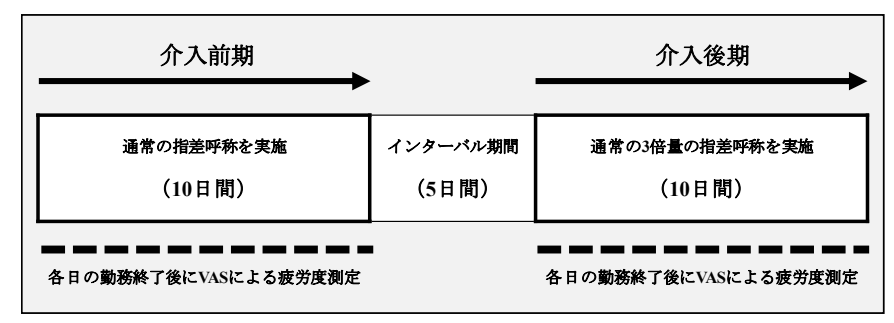

図 1. 研究フロー 
直線の左端を「疲れを全く感じていない状態」, 右 端を「想像できる最大の疲れを感じている状態」 として印をつけてもらい，左端からの距離を測定 して 100 点満点で評価した。 また, 研究期間中に 発生したヒューマンエラーの回数を計測した。本 研究におけるヒューマンエラーは, 品質及び安全 上の事故，インシデントおよびヒヤリハット事象 のうち人為的原因であるものとした。インシデン 卜は「事故に至る可能性があった出来事」と定義 し，ヒヤリハットは事故やインシデントに至らな かったが「『ひやっ』としたり，『はっ』としたり した出来事」と定義した。D 社福島工場では，各 生産ラインの責任者が管理部門にヒューマンエラ 一発生都度に報告をあげ，管理部門が集計するこ とになっている。

\section{5. 統計解析}

線形混合モデルを用いた対応のある二元配置の 分散分析により，介入前期と後期における各疲労 度得点の平均推定值の差とその 95\%信頼区間を算 出した。 介入前期と後期におけるヒューマンエラ 一の発生回数も同様に比較した. 有意水準は両側 $5 \%$ とし，統計ソフトウェア SPSS26.0J を用いて分 析を実施した。

3.6. 倫理的配慮

本研究は, D 製薬会社内の倫理委員会の承認を 受けて実施した（No.201901）。事前に対象者全員 に研究協力に関して書面による同意を得た.

\section{4. 結果}

対象者 30 名は男性が 26 名（87\%）であり，年 齢は 50 歳代が 16 名 (53\%) と最も多く, 次いで 30 歳代が 8 名 (27\%)，40 歳代が 4 名 (13\%), 20 歳代が 2 名 (7\%)であった. 対象者のうち 7 名 (23\%) が腰痛持ちであると申告していたが，日常業務に 支障のある障害や疾病を有する者はいなかった。

図 2 に, 介入前期と後期の VAS による疲労度得 点の平均值の経日変化を示した。 また, 表 1 に線 形混合モデルを用いた二元配置分散分析による固 定効果の検定結果を示した．指差呼称の回数を増 やすことにより，腕 $(\mathrm{p}=0.047)$, 目 $(\mathrm{p}=0.003)$, 精 神 $(\mathrm{p}=0.001)$ の各部位の疲労度が有意に増大した。 また, 腕 $(\mathrm{p}<0.001)$, 口 $(\mathrm{p}=0.006)$, 目 $(\mathrm{p}=0.032)$ ， 精神（ $p=0.004 ） の$ 各部位は，日数が経過するごと に疲労度が上昇する傾向も見られた。介入と日数

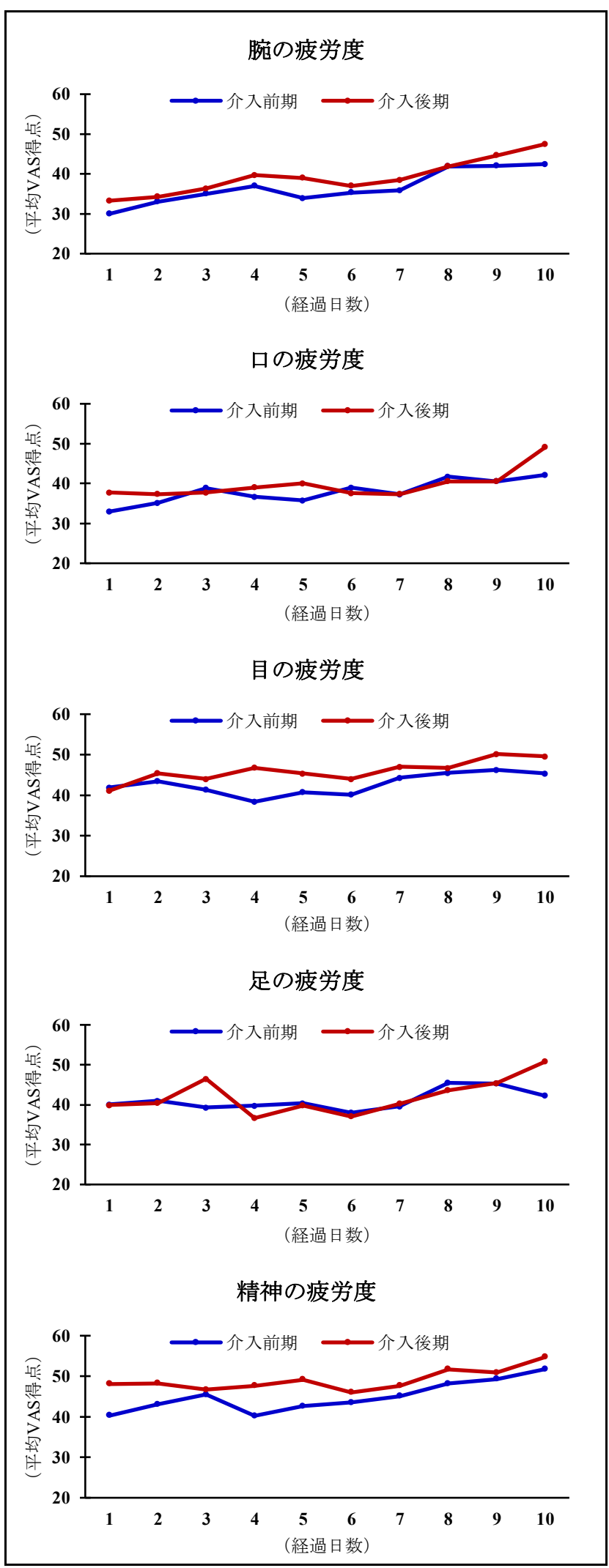

図 2. 介入前期（通常量の指差呼称） と介入後期（3 倍量の指差呼称）における各日の Visual Analog Scale による疲労度得点の平均值 
表 1. 線形混合モデルを用いた二元配置分散分析 による固定効果の検定結果

\begin{tabular}{cccc}
\hline & \multicolumn{3}{c}{$\mathrm{p}$ 值 } \\
\cline { 2 - 4 } & 介入 & 経過日数 & $\begin{array}{c}\text { 介入 } \\
\text { 経過日数 }\end{array}$ \\
\hline \hline 腕の疲労度 & 0.047 & $<0.001$ & 0.972 \\
口の疲労度 & 0.197 & 0.006 & 0.472 \\
足の疲労度 & 0.653 & 0.194 & 0.609 \\
目の疲労度 & 0.003 & 0.032 & 0.769 \\
精神の疲労度 & 0.001 & 0.004 & 0.886 \\
\hline
\end{tabular}

の経過との間に有意な交互作用が見られた部位は 無かった.

表 2 に, 線形混合モデルによって算出した介入 前期と後期の疲労度得点の差の推定平均值とその 95\%信頼区間を示した. 指差呼称の回数を 3 倍に することで, VAS による疲労度の推定平均值は, 腕で 2.4 (95\%信頼区間 : $0.3 \sim 4.7)$, 目で $2.9(95 \%$ 信頼区間：1.0４.9），精神で $3.9 （ 95 \%$ 信頼区間 : 1.7〜6.0)，有意に上昇した.

また, 介入前期および後期の計 20 日間をとおし て, 作業中のヒューマンエラーは 1 件も発生しな かった.

\section{5. 考察}

本研究では，医薬品製造工場の製造ラインにお ける指差呼称の実施回数を増やすことが，作業員 の主観的疲労度およびヒューマンエラーの発生回 数に影響するかどうか検討した。 その結果, 指差 呼称の実施回数を通常の 3 倍にすると, 腕と目の 肉体的疲労度および精神的疲労度が上昇すること が明らかとなった。一方, 短期的にはヒューマン エラーの発生回数に影響を及ぼさない可能性も示 唆された。過去の指差呼称の有効性評価に関する
研究はディスプレイ上もしくは模擬作業で実施さ れているものであり，実際の作業現場を対象とし た報告はこれまでに無かった。今回の研究成果は, 医薬品製造工場の実製造ライン上における指差呼 称に関する介入研究の報告として初めてのもので あり，製造現場における適切な指差呼称の実施回 数を決定するための基礎資料となることが期待さ れる。実際の作業現場においては，指差呼称の実 施個所や対象を増や寸傾向にあるところが多い. しかし, 本研究で指差呼称を増や寸と作業員の疲 労度が増大寸ることが明らかになったことに鑑み ると，新たに指差呼称を実施すべき個所や対象が できた場合には優先度の低いものを取り止める等, 意識的に実施回数をコントロールすることが必要 となってくると考えられる.

本研究により, 指差呼称の回数を増やすことで, 腕, 目, 精神といった各部位の疲労度が増大寸る ことが明らかとなった。指差呼称実施によって負 担がかかりやすい部位が明確になったことは，指 差呼称を起因とする疲労回復に対する効率的な休 㮩方法の策定の一助となると考えられる. 一方, 今回の検討では, 肉体的疲労度のうちロと足につ いては有意な変化がみられなかった。口の疲労度 に変化が見られなかった理由として，勤務時間中 の発声数に対し，指差呼称を 3 倍にしたことによ り増大した発声数が割合的に少なかったこと，ま た指差呼称における発生は自分自身に聞こえる最 小限度でよく，大きな声量を伴わないことがあげ られる。また，足の疲労度に変化が見られなかっ た点については，指差呼称の回数を増やしたとし ても歩数や足関節の屈伸回数は増加しないことが 理由として推察される.

今回の調査期間は介入前期が 10 日，後期が 10 日の計 20 日と短かく，また対象者が少数であった ことから，期間中にヒューマンエラーが一度も発

表 2. 介入前期と介入後期の Visual Analog Scale による疲労度得点の差の推定平均值

\begin{tabular}{ccccl}
\hline & \multicolumn{2}{c}{ 推定平均值 } & \multirow{2}{*}{ 推定平均值の差 } & (95\%信頼区間) \\
\cline { 2 - 3 } & 介入前期 & 介入後期 & & \\
\hline \hline 腕の疲労度 & 36.9 & 39.3 & 2.4 & $(0.3 \sim 4.7)$ \\
口の疲労度 & 38.4 & 39.8 & 1.4 & $(-0.7 \sim 3.6)$ \\
足の疲労度 & 41.4 & 42.1 & 0.7 & $(-2.3 \sim 3.7)$ \\
目の疲労度 & 43.0 & 45.9 & 2.9 & $(1.0 \sim 4.9)$ \\
精神の疲労度 & 45.3 & 49.2 & 3.9 & $(1.7 \sim 6.0)$ \\
\hline
\end{tabular}


生しなかった。そのため, 指差呼称の実施回数を 増やすことによるヒューマンエラーの発生回数の 変化を十分に検討することができなかった。この 点については，今後の検討課題である. なお，今 回の調査対象者が勤務する製造現場では，事故は 年 $1 \sim 2$ 件，インシデントは年 $5 \sim 6$ 件，ヒヤリ八 ット事例は年 10 件程度報告されている. 今回の検 討により，指差呼称実施回数の増加は短期的には ヒューマンエラーの発生回数に影響しないことが 示唆されたとはいえ，長期的なインパクトは不明 である。特に，先行論文において過剩に指差呼称 を行うことで疲労により却ってエラーを増加させ

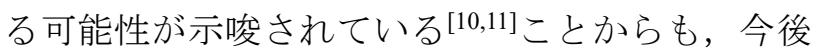
は対象者を増やし, より長期的な観察期間を設定 して, 指差呼称の実施回数とヒューマンエラーの 発生との関係を評価していく必要がある。

本研究には以下の限界点が挙げられる。まず, 本研究のデータは単一の製薬工場の作業員から得 られたものであり, 結果の一般化可能性に疑念が 残る。 そのため, 他の製薬工場や作業内容の異な る作業員を対象とした場合にも同様の結果が得ら れるかどうか, 今後調查が必要である. 次に, 今 回の研究では, 部位別の疲労度を簡便に測定する ためにVASによる主観的疲労度得点をアウトカム として採用した。 そのため, 疲労度の尺度として は信頼性・妥当性が高くない可能性がある。バイ オマーカー測定など, より客観性が高く, 再現性 のある疲労度測定方法を用いた調査によって結果 を確認する必要があると考えられる。

\section{6. 結論}

医薬品製造工場の実生産ラインにおいて，指差 呼称の実施回数を通常の 3 倍に増やすと, 腕や目 といった部位の肉体的疲労度および精神的疲労度 が上昇する一方で，短期的にはヒューマンエラー の発生回数に影響を及ぼさない可能性が示唆され た。

\section{引用文献}

[1] 鎌形剛三. あなたのヒヤリハット KY (安全衛 生実践シリーズ). 中央労働災害防止協会, 2004

[2] 中央労働災害防止協会. 危険予知活動トレー ナー必携改訂第 3 版, 2015

[3] 中央労働災害防止協会. 危険予知訓練 (ゼロ 災実践シリーズ) 第 4 版, 2015
[4] Shinohara, Kazumitsu et al. The effects of "finger pointing and calling" on cognitive control processes in the task-switching paradigm. International Journal of Industrial Ergonomics. 2013, 43, p.129-136

[5] Iwasaki, Masahiro et al. Pointing gesture recognition using compressed sensing for training data reduction. UbiComp '13 Adjunct: Proceedings of the 2013 ACM conference on Pervasive and ubiquitous computing adjunct publication. 2013, p.645-652

[6] 清宮栄一ほか. 複雑選択反応における作業方 法と Performance との関係について一「指差・喚呼」 の効果についての予備的検討一. 鉄道労働科学. 1965, 17, p.289-295.

[7] 芳賀繁ほか.「指差呼称」のエラー防止効果の 室内実験による検証.産業・組織心理学研究. 1996, 9(2), p.107-114.

[8] 飯山雄次. 指差唱呼の効用と応用: その科学的 背景. 安全. 1980, 31(12), p.28-33.

[9] 篠原一光ほか. 指差喚呼と視覚的注意の定位. 日本心理学会第 71 回大会発表論文集. 2008,p.1396 [10] 桜庭恵ほか. 看護師の疲労とインシデントの 関係性ーインシデント多発時間の現状分析から考 える安全性の向上一. 第 27 回東京医科大学病院看 護研究集録. 2007, p.31-34

[11] Jian Ai Yeow et al. Effects of Stress, Repetition, Fatigue and Work Environment on Human Error in Manufacturing Industries. Journal of Applied Sciences. 2014, 14, p.3464-3471

[12] 厚生労働省. 医薬品, 医療機器等の品質, 有 効性及び安全性の確保等に関する法律. 1960

[13] 厚生労働省. 危険性又は有害性等の調查等に 関する指針. 2006

[14] 日本疲労学会. 抗疲労臨床評価ガイドライン. 2011 


Abstract
"Pointing and calling" refers to pointing at important indicators and calling out the name and status for the
purpose of safety confirmation and human error prevention. In Japan, pointing and calling is recommended
in every industry as an effective safety measure, and it is widely practiced in medical settings and
manufacturing. This study examined changes in the degree of physical and mental fatigue and the amount of
human error with the increase in amount of pointing and calling in an actual production line at a
pharmaceutical manufacturing plant. We measured the degree of fatigue of the arms, mouth, eyes, and feet,
and mental fatigue of 30 workers at a pharmaceutical manufacturing plant in the Fukushima Prefecture at the
end of a work day over the span of 10 days using a visual analogue scale. Next, the workers were asked to
perform three times as much pointing and calling as they usually did. The degree of fatigue was similarly
measured for 10 days and then compared with the previous results. In comparison with the period during
which the usual amount of pointing and calling was performed, the degree of fatigue of the arms and eyes
and mental fatigue significantly increased during the period when the amount of pointing and calling was
increased threefold (p $<0.05$ ). No significant change in the degree of fatigue of the mouth and feet was
observed. Further, no human error occurred during the entire period of this study. The findings suggest that
increasing the amount of pointing and calling may increase the degree of fatigue experienced by workers,
while it may not affect the amount of human error in the short term. However, the period of observation ( 20
days) in this study may not have been sufficient to capture adequately the changes in the amount of human
error. The relation between the amount of pointing and calling and human error needs to be examined further
by conducting long-term observations.

(受付日：2019 年 12 月 24 日，受理日：2020 年 6 月 22 日）

数土 武一郎（すどたけいちろう）

現職 : 同仁医薬化工株式会社統括部部長

東海大学法学部卒業

製造業における HSE および BCP を専門とする，安全管理手法の開発と効果検証に関する研究を行っ ている。 